These experiments are compatible with the hypothesis that the plasma of patients with Hageman trait is not deficient in kallikreinogen but lacks either kallikreinogenase itself or some prior enzymic step required for its activation by acetone or 'Celite'. Whether the vasodilator activity released from human plasma by the various methods of activation is due to the release of a single proteinase cannot as yet be unequivocally stated. However, plasmin, because of its relatively low potency in producing vasodilata. tion $^{5}$, cannot be one of the proteinases involved. Similarly, the question of the identity of plasma kallikrein with the permeability factor and the glassactivated proteinase in human plasma cannot as yet be resolved. The results provide evidence that a common mechanism is involved in their release, but this does not exclude the possibility that the enzymes themselves may be different. Certainly, however, the simplest hypothesis would be that they were the same substance. Keole ${ }^{11}$ has reported that salivary and urinary kallikrein form kallidin in the absence of component $B$ and in the presence of soybean trypsin inhibitor. It would be of interest to know whether plasma kallikrein, which is inhibited by soybean trypsin inhibitor, produces kallidin by a process dependent on component $B$.

This work was supported in part by grants from the National Heart Institute, National Institutes of Health, U.S. Public Health Service, and the American Heart Association.

\section{E. Webster}

National Heart Institute, Bethesda, Maryland.

\section{O. D. RATNOFH*}

Western Reserve University School of Medicine and University Hospitals of Cleveland, Cleveland, Ohio.

- Career investigator, the American Heart Association.

1 Ratnoff, O. D., and Colopy, J. E., J. Clin. Invest., 34, 602 (1955).

- Ratnoff, O. D., Bageman Trait, Thrombosis et Diath. Hamor., 4, Supp. 116 (1960).

s Margolis, J., A ustral. J. Exp. Biol., 37, 239 (1959).

- Margolis, J., J. Physiol., 151, 238 (1960).

- Webster, M. E., and Pierce, J. V., J. Pharm. Exp. Therap., 130 484 (1960).

- Werle, E., Polypeptides which Stimulate Plain Muscle, edit. by Gaddum (E. and S. Livingstone, 1955).

- Werle, E., Forell, M. M., and Maier, L., Arch. Exp. Path. Pharmakol. 225,369 (1955).

- Waaler, B. A., Scand. J. Clin. Lab. Invest., 11, Supp. 37 (1959).

- Ratnoff, O. D., Davie, E. W., and Mal)ett, D. L., J. Clin. Invest., 40, 803 (1961).

" Ratnoff, O. D., Hartmann, R. C., and Conley, C. L., J. Exp. Med., 81, 123 (1950)

$"$ Keele, C. A., in Polypeptides which affect Smooth Muscles and Blood Vessels, edit. by Schachter (Pergamon Press, 1960).

\section{Presence of Two Iron-Transport Proteins in Serum}

THE iron-binding protein transferrin was isolated in crystalline state as early as 1952 , and it has been generally accepted that this was the only ironconteining protein in serum under normal conditions.

Using electrophoresis in starch süpporting medium according to Kunkel and Slater ${ }^{1}$ and iron-59 determinations after electro-plating, it is possible to detect minor variations in the electrophoretic pattern which are not in agreement with this point of view. The experiments were performed on human beings and the results are given in Table 1.

When serum and ${ }^{58} \mathrm{Fe}$ are incubated for $15 \mathrm{~min}$. and investigated by electrophoresis, $11 \cdot 7$ per cent of

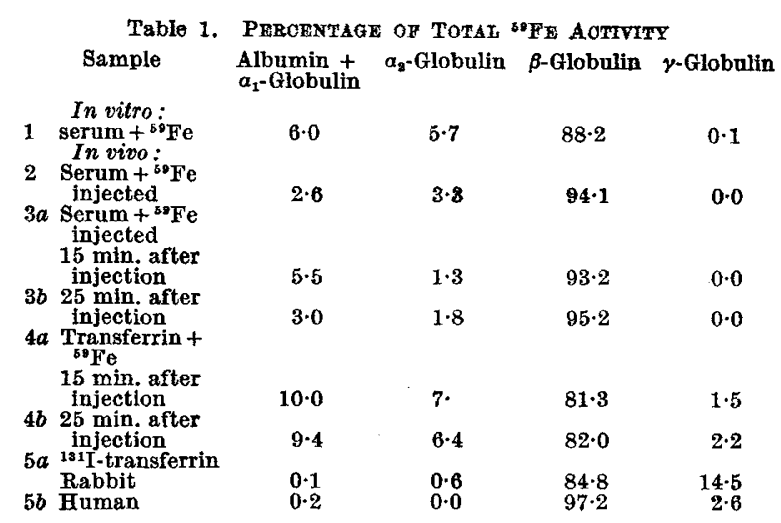

the ${ }^{6}{ }^{\circ} \mathrm{Fe}$ is found in front of the transferrin containing $\beta$-globulin. It must be noted that no activity is found in the $\gamma$-globulin.

When serum from a patient is incubated with ${ }^{50} \mathrm{Fe}$ and re-injected, the serum from the patient shows the same type of pattern. It is of interest to note that two samples taken after an interval of $10 \mathrm{~min}$. show the same relative distribution although the activity has decreased by 25 per cent from the first to the second sample.

If the ${ }^{50} \mathrm{Fe}$ is incubated with transferrin (Behringwerke) we find again the same pattern with a splitting of the ${ }^{B \theta} \mathrm{Fe}$ into more than one protein fraction.

The electrophoretic findings are in many ways identical with the effect of a protein-protein interaction. This could, however, be shown not to be the case. If iodine-131-labelled transferrin is injected into a rabbit or in a man, ${ }^{181} I$ is found only at the expected place for transferrin and not where the fast fraction of the ${ }^{59} \mathrm{Fe}$ was found.

The results can therefore only be taken to indicate that serum contains a protein which is not identical with transferrin and which has the ability to bind ${ }^{80 \mathrm{Fe}}$ reversibly.

The constant relative size of the fast fraction in experiments $4 a$ and $b$, where the iron was injected bound to transferrin, makes it probable that this smaller fraction may even represent an intermediary stage between transferrin and the erythroblasts.

The presence of such an intermediate in serum has been suggested by the work of Najean, Ardaillou and Bernard ${ }^{2}$. They showed that the rate of iron transfer from transferrin to reticulocytes could be augmented by adding serum to the system. The active component was non-dialysable and thermolabile.

In the ghosts of erythrocytes from animals injected. with ${ }^{59} \mathrm{Fe}$ Falbe-Hansen and Lothe ${ }^{3}$ found an ironcontaining fraction which could not be identified with known iron proteins. This fraction appeared to be an intermediate stage in iron transport as it could only be found during the first hours after the ${ }^{39} \mathrm{Fe}$ injection. The possibility of identity between these two fractions is being investigated.

M. FABER

R. JORDAI

Finsenlaboratory,

Finseninstitutet og Radiumstationen, Copenhagen.

${ }^{1}$ Kunkel, H. G., and Slater, R. J., Proc. Soc. Exp. Biol. Med., 80, 42 (1952).

2 Najean, Y., Ardaillou, R., and Bernard, J., Rev. Frans. Etud. Clin. Biol., 5, 783 (1960).

- Falbe-Fansen, I., and Lothe, K., Acta Physiol. Scand. (in the press). 